\title{
SOIL AGGREGATION IN A CROP-LIVESTOCK INTEGRATION SYSTEM UNDER NO-TILLAGE ${ }^{(1)}$
}

\author{
Edicarlos Damacena de Souza ${ }^{(2)}$, Sérgio Ely Valadão Gigante de Andrade Costa ${ }^{(3)}$, \\ Ibanor Anghinoni ${ }^{(4)}$, Paulo César de Faccio Carvalho ${ }^{(5)}$, Eric Victor Ferreira de \\ Oliveira $^{(6)}$, Amanda Posselt Martins ${ }^{(7)}$, Eduardo Cao ${ }^{(7)}$ \& Marcelo Andrighetti ${ }^{(7)}$
}

\section{SUMMARY}

Grazing intensities can influence soil aggregation, which can be temporarily and permanently affected. The objective of this study was to evaluate the aggregate stability in water at the end of a soybean cycle and during pasture development in a crop-livestock integration system under no-tillage and grazing intensities. The experiment was initiated in 2001, in a dystrophic Red Latosol, after soybean harvest. Treatments consisted of pasture (black oat + Italian ryegrass) at heights of 10, 20 and $40 \mathrm{~cm}$, grazed by young cattle, and a control (no grazing), followed by soybean cultivation, in a randomized block design. Soil samples were collected at the end of the soybean cycle (May/2007), during animal grazing (September/2007) and at the end of the grazing cycle (November/2007). The grazing period influences aggregate distribution, since in the September sampling (0-5 cm layer), there was a higher proportion of aggregates $>4.76 \mathrm{~mm}$ at all grazing intensities. Soil aggregation is higher in no-tillage crop-livestock integration systems in grazed than in ungrazed areas.

Index terms: black oat, Italian ryegrass, mean weighted diameter, soil structure.

\section{RESUMO: AGREGAÇÃO DO SOLO EM SISTEMA DE INTEGRAÇÃO LAVOURA-PECUÁRIA EM PLANTIO DIRETO}

As intensidades de pastejo podem influenciar o estado de agregação do solo, que pode sofrer alterações temporárias ou permanentes. Oobjetivo deste estudo foi avaliar a estabilidade

\footnotetext{
(1) Received for publication in October 2009 and approved in April 2010.

(2) Post doctorate student at the Department of Soil Science, Federal University of Goiás, Campus of Jataí. Rod BR 364, km 192. Setor Industrial, Jataí (GO). E-mail: edicarlos@pq.cnpq.br

(3) Doctorate student at the Departement of Soil Science, Federal University of Rio Grande do Sul - UFRGS. E-mail: sergioelycosta@hotmail.com

(4) Professor of the Department of Soil Science, UFRGS. CNPq researcher. E-mail: ibanghi@ufrgs.br

(5) Professor of the Forage and Agrometeorology Department, UFRGS. CNPq researcher. E-mail: paulocfc@ufrgs.br

(6) Doctorate student at the Department of Soil and Plant Nutrition of the Federal University of Viçosa - UFV. E-mail: ericsolos@yahoo.com.br

(7) Agronomy Graduate Students. Scientific Scholarship of the Federal University of Rio Grande do Sul - UFRGS. Emails: amandaposselt@gmail.com; duda_cao@yahoo.com.br; 00135966@ufrgs.br
} 


\begin{abstract}
dos agregados em água ao final do ciclo da soja e durante o desenvolvimento da pastagem em sistema de integração lavoura-pecuária em plantio direto submetido a intensidades de pastejo. O experimento foi iniciado em 2001, em um Latossolo Vermelho distrófico, após a colheita da soja. Os tratamentos constaram de alturas de manejo da pastagem (aveia-preta +azevém): 10, 20 e $40 \mathrm{~cm}$, com bovinos jovens, e sem pastejo, seguido do cultivo de soja, em delineamento de blocos ao acaso. Amostras de solo foram retiradas nas camadas de 0 a 5, 5 a 10 e 10 a $20 \mathrm{~cm}$. As amostras foram coletadas ao final do ciclo da soja (maio/2007), em pleno pastejo pelos animais (setembro/2007) e ao final do pastejo (novembro/2007). O tempo em que os animais permanecem em pastejo influencia a distribuição de agregados no solo, uma vez que, na coleta do mês de setembro, na camada de 0 a $5 \mathrm{~cm}$, houve maior proporção de agregados maiores que 4,76 mm em todas as intensidades de pastejo. Sistemas de integração lavourapecuária submetidos ao pastejo em plantio direto promovem maior agregação do solo em relação às áreas não pastejadas.
\end{abstract}

Termos de indexação: aveia-preta + azevém, diâmetro médio ponderado, estrutura do solo.

\section{INTRODUCTION}

In the state of Rio Grande do Sul an area of five million hectares is cultivated in the Summer under no-tillage, of which around three million hectares are used to grow black oat and ryegrass in the winter. These two species have a high grazing potential and can be used for cattle grazing, allowing agriculture and livestock integration. Thus, crop-livestock integration is an alternative for profit diversification, diminishing the farmers' dependence on the summer crops, reducing farming risks. Farmers who work with integrated crop livestock system in this state have generally adopted summer soybean followed by black oat and ryegrass grazing in the winter. However, studies on the impact of this system on animal-plant-soil-atmosphere interrelations must advance at the same pace as the use of this system.

Aggregate stability is one of a set of properties that characterize soil quality, as proposed by Karlen \& Stott (1994), in a conceptual index related to soil resistance to degradation. In Brazil, trials evaluating these soil quality indicators, both in the South (Silva et al., 2000; Conceição, 2006; Boeni, 2007) and the Cerrado region (Beutler et al., 2001), have quantified aggregate stability indexes and aggregate distribution by size class, establishing relations with chemical and physical properties in various soil and crop tillage systems.

Soil aggregate stability can result from the mechanical union of soil particles by cells and hyphens of organisms, by cementing effects of products derived from microbial synthesis or by the stabilizing action of residue decomposition, with individual or combined action (Baver et al., 1973). The management will influence soil aggregation and may cause temporary or permanent alterations. Reinert (1993) found great seasonal variation in soil aggregation and concluded that short-term evaluations can result in misleading interpretations. Seasonal variations in the structural stability of soils vary with the physical processes related to tilling, machine traffic, climate and plant growth. According to Allison (1973), plants play a greatly beneficial role in soil aggregation, due to the thin roots branching out into the soil, predisposing aggregation. Furthermore, roots constantly remove water from the soil, creating dry regions and, by exudation, providing rizosphere microorganisms with energy, which influence aggregation directly or indirectly. Grasses (gramines), with higher root density and better root distribution in the soil, favor bonding points between mineral particles and aggregates, contributing to aggregation and stability, and can be used as soil structure recovery plants in degraded areas (Silva \& Mielniczuk, 1997).

Various authors have stated a direct relation between aggregation and $\mathrm{C}$ content in the soil (Conceição, 2006; Boeni, 2007; Salton et al., 2008), demonstrating that soil $\mathrm{C}$ content variations come to play an important role in trials involving aggregation, due to greater or lesser organic matter protection. However, there is no consensus regarding increase in soil C contents due to management practices (soil and crop), since some reports do not show these increases in clayey soils with high oxide contents (Bayer et al., 2000), while other authors (Salton et al., 2008; Souza et al., 2008) verified carbon increases in these soils.

There are practically no studies on grazing effects in soil aggregation, since trials related to aggregation in management systems with animals, are not only few, but also evaluate solely soil management systems compared to native grassland or permanent pasture (Salton et al., 2008). Studies on the effects of grazing period and intensity on soil aggregation in integrated crop-livestock systems are scarce in Brazil. This indicates the need of verifying effects of the grazing period on soil aggregation, and consequently, on the physical protection of soil organic matter, in view of the direct relation between aggregation and carbon accumulation in the soil.

Therefore, in integrated crop-livestock system production under no-tillage an increase in macroaggregates is expected with decreasing grazing intensity, due to increases in remaining residue contents. Also, even at low grazing intensities, aggregation will increase with grazing cycles and 
system development over the course of time. On this background, the objective of this study was to evaluate aggregate stability in water after soybean cycle and during pasture development in integrated croplivestock system under no-tillage subjected to different grazing intensities.

\section{MATERIALS AND METHODS}

The experiment was established in May 2001, on the Espinilho Farm (Agropecuária Cerro Coroado), in São Miguel das Missões, in the region Planalto Médio - state of Rio Grande do Sul, Brazil (29 ${ }^{\circ} 03^{\prime} 10$ " S latitude and $53^{\circ} 50$ ' 44 "W longitude). The soil, a clayey Red Latosol (Embrapa, 2006), contained 540, 270 , and $190 \mathrm{~g} \mathrm{~kg}^{-1}$ clay, silt and sand, respectively, in the 0-20 cm layer. According to the Köppen classification, the regional climate is humid subtropical (Cfa). Before the experiment, crops had been grown under no-tillage for 10 years, with black oat (Avena strigosa Schreb) during the winter and soybean (Glycine max) during summer. In Autumn 2001, after soybean harvest, the experiment was initiated by sowing black oat + Italian ryegrass (Lolium multiflorum Lam.).

After the grazing and soybean cycles, soil was sampled to evaluate soil physical and chemical properties, occurring in May and November, respectively. This chronogram was executed since May 2001. Before establishing the first soybean cycle, in November 2001, 6.0 $\mathrm{Mg} \mathrm{ha}^{-1}$ lime was broadcast across the whole area, which is the amount recommended to raise the soil $\mathrm{pH}$ in consolidated notillage (10 years), up to 5.5 , in the $0-10 \mathrm{~cm}$ layer. (CQFS RS/SC, 2004).

The experimental area, of approximately 22 ha, was divided in 12 plots ranging from 1.0 to 2.5 ha, for treatments with different pasture heights: 10, 20, 30 and $40 \mathrm{~cm}$ (G-10, G-20, G-30 and G-40, respectively), and no grazing (NG) representing grazing intensities, distributed in a randomized block design, with three replications. The grazing heights were measured every 14 days by the Sward stick method (Bircham, 1981). For the present study, G-10, G-20, G-40 and NG treatments were selected. Pasture height was controlled by removing the animals when the it was shorter than desired and vice-versa. On average, the number of animals in each experimental plot was four, two and one for grazing heights of 10,20 and $40 \mathrm{~cm}$, respectively. Grazing was continuous and began in the first half of July and ended in the first half of November, with animal entrance when pasture reached average dry matter accumulation of around $1,500 \mathrm{~kg} \mathrm{ha}{ }^{-1}$. Young cattle, around 12 months old (around $260 \mathrm{~kg}$ ), were used. Around 45 days after pasture sowing, $\mathrm{N}$ top dressing of around $70 \mathrm{~kg} \mathrm{ha}^{-1}$ $\mathrm{N}$ was applied as urea in each growing season. The same amount of $\mathrm{N}$ was applied for all treatments in all seasons, i.e., $\mathrm{N}$ fertilization is not a source of variation.

After grazing, the pasture area was desiccated with glyphosate herbicide to sow no-tillage soybean in November of each year (Reunião..., 2004). The cultivar Iguaçu was planted with $45 \mathrm{~cm}$ interrow spacing. Base fertilization consisted of $300 \mathrm{~kg} \mathrm{ha}^{-1}$ of 0-20-30, 5-20-20, 0-20-30, 0-20-30, 0-20-30, and 0-20-30 NPK mixtures in the 2001/02, 2002/03, 2003/ 04, 2004/05, 2005/06 and 2006/07 growing seasons, respectively, as recommended for a grain yield of $4.0 \mathrm{t} \mathrm{ha}^{-1}$ (CQFS RS/SC, 2004), and seeded with specific seed inoculants, based on data of soil analysis. Soybean was harvested from April to May every year.

For this study, soil samples were first collected (May of 2007) in the 0-10 cm layer, at the different grazing intensities (10, 20 and $40 \mathrm{~cm}$ and no grazing), for characterization of the physical and organic matterrelated properties (Table 1). Shoot dry matter for grazing intensities in soil sampling periods was also evaluated (Table 2). To verify the influence of grazing intensity on aggregation, the soil was sampled in the layers $0-5,5-10$ and 10-20 cm, three times: at the end of the soybean cycle (beginning of May 2007), under

Table 1. Physical properties, total organic carbon, particulate organic matter carbon, total nitrogen and particulate organic matter nitrogen, in the layer 0-10 cm of a Red Latosol under a no-tillage integrated crop-livestock system and different grazing intensities (May/2007)

\begin{tabular}{|c|c|c|c|c|c|c|c|c|c|c|}
\hline Grazing intensity ${ }^{(1)}$ & Ds & TPV & Ma & Mi & TOC & POC & POC/TOC & $\mathrm{TN}$ & N-POM & N-POM/TN \\
\hline & $\mathrm{kg} \mathrm{dm} \mathrm{m}^{-3}$ & 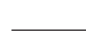 & $\mathrm{m}^{3} \mathrm{~m}^{-3}$ & - & \multicolumn{2}{|c|}{$-\mathrm{g} \mathrm{kg}^{-1} \_$} & $\%$ & \multicolumn{2}{|c|}{$\mathrm{g} \mathrm{kg}^{-1}$} & $\%$ \\
\hline$G-10$ & 1.37 & 0.51 & 0.07 & 0.44 & 24.0 & 3.1 & 12.9 & 2.1 & 0.26 & 12.4 \\
\hline $\mathrm{G}-20$ & 1.31 & 0.54 & 0.09 & 0.45 & 27.1 & 4.1 & 15.1 & 2.3 & 0.37 & 16.1 \\
\hline $\mathrm{G}-40$ & 1.32 & 0.53 & 0.09 & 0.44 & 26.3 & 4.1 & 15.6 & 2.3 & 0.35 & 15.2 \\
\hline NG & 1.31 & 0.55 & 0.11 & 0.44 & 26.9 & 4.8 & 17.8 & 2.4 & 0.36 & 15.2 \\
\hline
\end{tabular}

\footnotetext{
(1) G-10, G-20, G-40 and NG represent grazing heights of 10, 20 and $40 \mathrm{~cm}$ and no grazing, respectively. Ds: soil density, TPV: total pore volume, Ma: macro-porosity, Mi: micro-porosity, TOC: total organic carbon, POC: particulate organic matter carbon, TNtotal nitrogen, N-POM: particulate organic matter nitrogen.
} 
Table 2. Soybean and pasture shoot dry matter (litter + plant shoot) in a Red Latosol under integrated croplivestock system and no-tillage under different grazing intensities, in 2007

\begin{tabular}{cccccc}
\hline & \multirow{2}{*}{$\begin{array}{c}\text { Soybean } \\
\text { Grazing intensity }\end{array}$} & \multicolumn{3}{c}{ Pasture } \\
\cline { 3 - 5 } & May & July & September & November & Average \\
\cline { 3 - 5 } & & & & Mg ha \\
G-10 & 2.45 & 1.22 & 0.83 & 0.48 & 0.85 \\
G-20 & 2.85 & 1.17 & 2.28 & 3.94 & 1.80 \\
G-40 & 2.02 & 1.50 & 5.13 & 5.89 & 5.36 \\
NG & 2.75 & 1.35 & 3.96 & 2.94 & - \\
Média & 2.51 & 1.31 & & \\
\hline
\end{tabular}

${ }^{(1)}$ G-10, G-20, G-40 and NG represent grazing heights of 10, 20 and $40 \mathrm{~cm}$ and no grazing, respectively.

full grazing (mid-September 2007) and at the end of the grazing period, immediately after animal removal (mid-November 2007). Soil samples were filled in plastic pots and transported in paper boxes for soil structure conservation. Then the samples were airdried until friable and crumbled manually, observing the weakness points and sieved through $9.52 \mathrm{~mm}$ mesh, removing plant fragments and other non-soil components, rocks and gravel.

Aggregate stability was determined as described by Kemper \& Chepil (1965), with modifications proposed by Carpenedo \& Mielniczuk (1990) and Silva \& Mielniczuk (1997b), based on the separation of aggregates into size classes by dispersion and wet sieving, with the exclusion of individual particles.

Mean weighted diameter (MWD) was calculated from values obtained by the following equation:

$$
M W D=[\Sigma(A G R i x d i / \Sigma A G R]
$$

where di $=$ average class diameter $i$, obtained by [ (upper mesh + lower mesh $) / 2] ; A G R i=(m A G R i / \Sigma A G R) x$ 100, where AGR $i=$ aggregate class percentage $i$; mAGR $i=$ aggregate mass class $i ; \Sigma$ AGR $=$ total aggregate mass.

Particulate and total carbon were analyzed by dry combustion using Shimadzu TOC-V CSH highsensitivity TOC analyzer. Total and particulate organic matter nitrogen (TN) were determined by the Kjeldahl method, according to Tedesco et al. (1995). Organic matter fractions were determined according to Cambardella \& Elliot (1992) and the stocks based on soil equivalent mass and $\mathrm{C}$ content.

Results were subjected to variance analysis, using the Tukey test at $5 \%$ and the following statistical model for variance analysis (ANOVA):

$$
\begin{gathered}
\text { Yijk }=\mu+\text { Bi }+ \text { Aj }+ \text { error } a(i, j)+C k+\operatorname{error} b(i, k)+ \\
\text { ACjk }+ \text { error c }(i, j, k)
\end{gathered}
$$

where: $\mathrm{B}=$ blocks $(\mathrm{i}=1,2,3) ; \mathrm{A}=$ grazing intensities $(\mathrm{j}=1,2,3,4) ; \mathrm{C}=$ sample layers $(\mathrm{k}=1,2,3)$.
For variance analysis between sampling periods for mean weighted diameter, the same statistical model was used, changing factor "A", of the model, denominated for grazing intensities, to sampling periods $(j=1,2,3)$, since this analysis was performed comparing averages for each grazing intensity.

\section{RESULTS AND DISCUSSION}

Variations in soil mass in relation to water-stable aggregate distribution among grazing intensities were greater in larger aggregates $(>2.00 \mathrm{~mm})$ in the three evaluations (Tables 3 and 5), but mainly in the first (Table 3). In this evaluation (May 2007), after soybean harvest and before pasture establishment, grazing intensity effects were observed in the three evaluated layers and the three greatest aggregate sizes. This effect is a result of the period (six years) of use as crop-livestock integration under no-tillage, since sampling occurred immediately after soybean cultivation (2006/2007 growing season), with absence of animals for at least six months. Since animal presence favors higher aggregation $(4.76-9.52 \mathrm{~mm})$ especially at moderate grazing intensities (20 and $40 \mathrm{~cm}$ grazing height), the inverse behavior was observed (higher magnitude) in the absence of animals (no grazing) with distribution of aggregates between 2.0 and 4.76 for all sampled layers. This demonstrates a hierarchy in aggregation. A higher frequency of 1.0-2.0 $\mathrm{mm}$ aggregates also occurred in the absence of animals (NG) in the layers 5-10 and 10-20 cm, respectively (Table 3 ).

A greater proportion of larger aggregates (4.76 to $9.52 \mathrm{~mm}$ ) at the moderate grazing intensities (G-20 and G-40), compared the ungrazed treatment, with inverse effect in the aggregate distribution with diameter between 2.0 and $4.76 \mathrm{~mm}$, also occurred in the later evaluations: September (Table 4), period of pasture development (Table 2), in December (Table 5), and in the end of the grazing period (Table 2). 
Table 3. Soil mass distribution as water-stable aggregates in different layers in a Red Latosol under integrated crop-livestock system under no-tillage under different grazing intensities (May/2007)

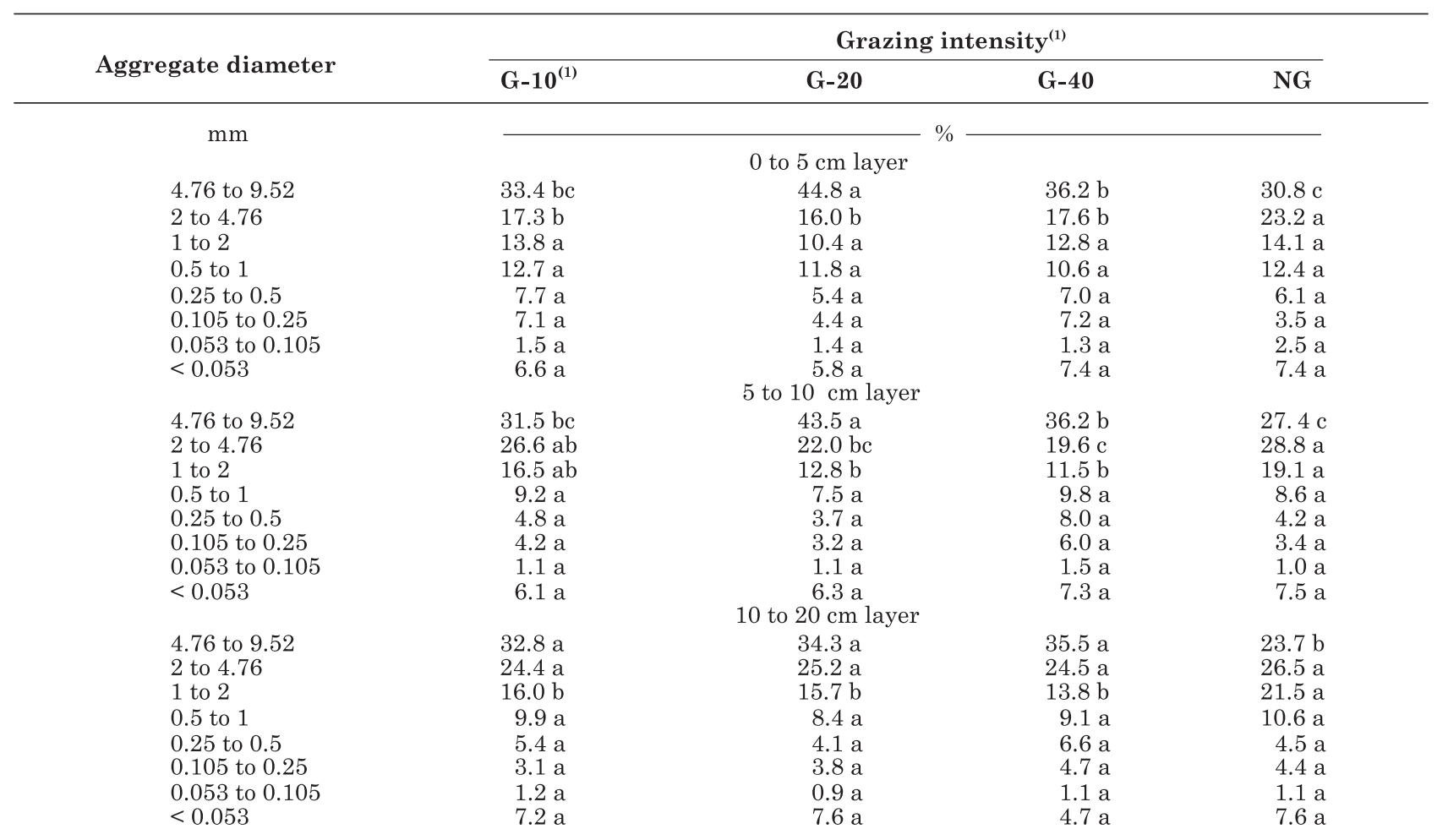

(1) G-10, G-20, -40 and NG represent grazing heights of 10, 20 and $40 \mathrm{~cm}$ and no grazing, respectively. Averages followed by a same letter in a row did not differ from each other by the Tukey test at $5 \%$.

Table 4. Soil mass distribution as water-stable aggregate diameter in different layers in a Red Latosol under integrated crop-livestock system under no-tillage under different grazing intensities (September/2007)

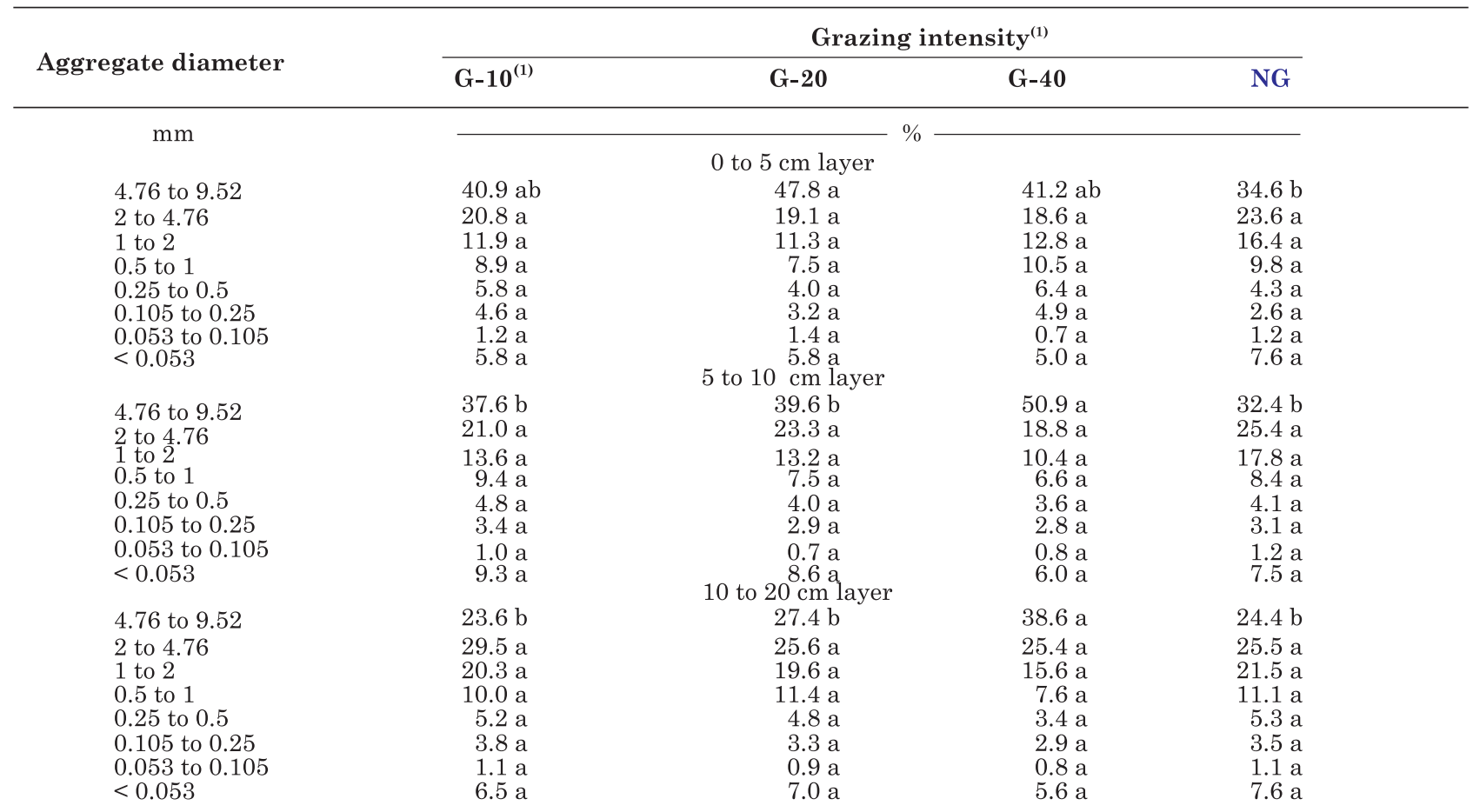

(1) G-10, G-20, -40 and NG represent grazing heights of 10, 20 and $40 \mathrm{~cm}$ and no grazing, respectively. Averages followed by the same letter, in the lines, averages followed by the same small letters in the rows do not differ from each other by the Tukey test at $5 \%$. 
Table 5. Soil mass distribution as water-stable aggregates diameter in different layers in a Red Latosol under integrated crop-livestock system under no-tillage under different grazing intensities (November/ 2007)

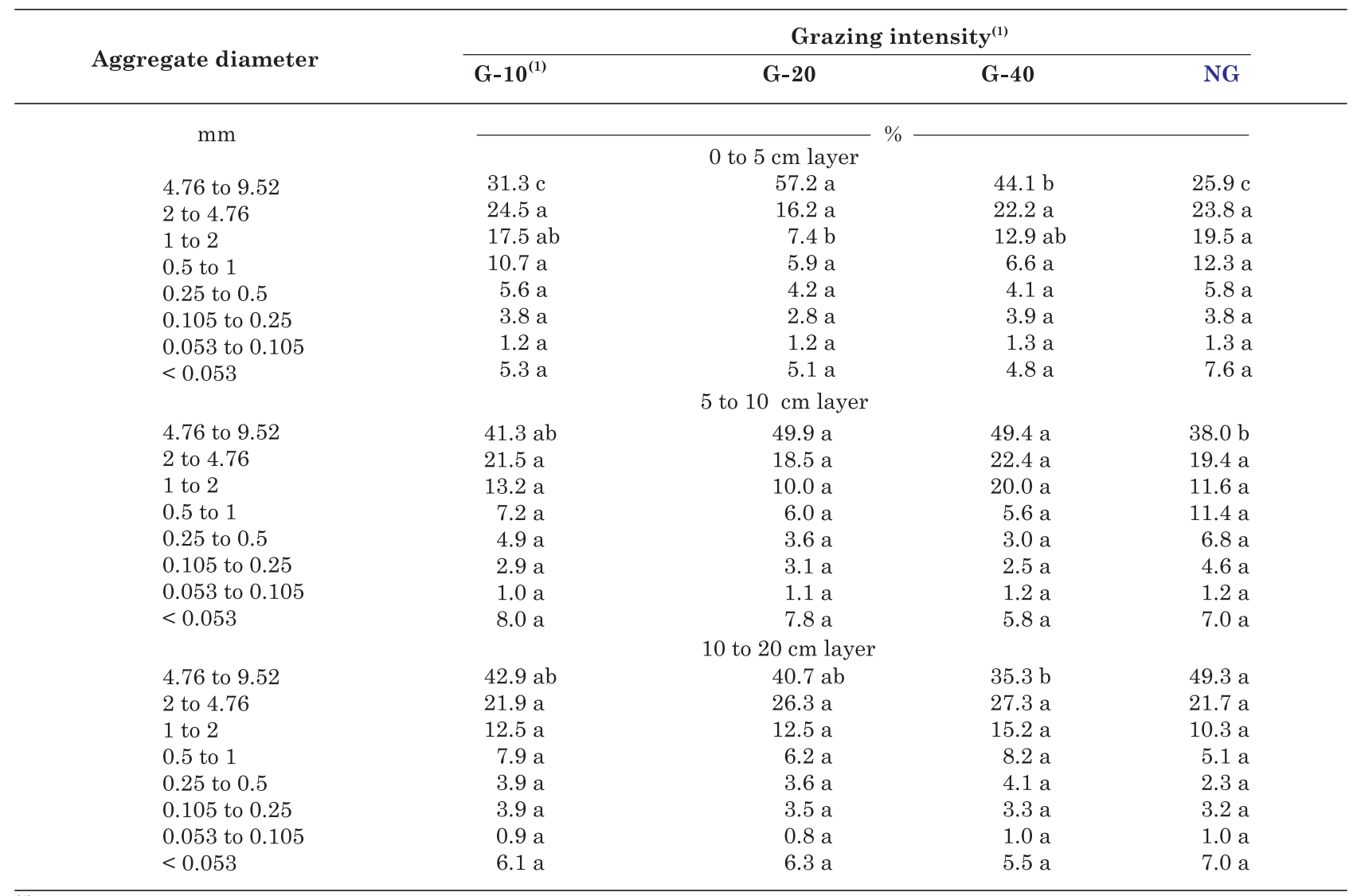

(1) G-10, G-20, G-40 and NG represent grazing heights of 10, 20 and $40 \mathrm{~cm}$ and no grazing, respectively. Averages followed by the same letter, in the lines, averages followed by the same small letters in the rows do not differ from each other by the Tukey test at $5 \%$.

Soil aggregation improvement by animal presence (grazing) can be related, at least to a certain level (moderate grazing (Tables 3 and 5), to an increase in the amount of pasture roots with increasing grazing pressure (Conte, 2007; Souza et al., 2008). It can also be explained by the higher organic matter contents (total carbon and nitrogen and fractions) (Table 1) that improve soil quality over time as well as to the absence of tillage.

The low effect of grazing intensities on small aggregate $(<1.0 \mathrm{~mm})$ distribution was probably due to the forces that hold particles together and maintain the formed aggregates (Conceição, 2006). Therefore, residues applied to the soil (Table 2) act as organic nucleus on aggregation. From this standpoint, when the decomposition organic residue begins, microbial exudate release stabilizes the aggregates and, according to the decomposition of the organic matter nucleus, the production of binding agents decreases until the larger aggregates are broken down into smaller ones (Oades, 1984). Therefore, with constant residue addition to the soil, these small structures are rearranged into larger structures, which remain stable until energy bonds of the stabilizing agent are weaker than the energy of external agents acting on aggregates (Dexter, 1988). This shows the great importance of maintaining constant energy and organic matter fluxes (organic residues), which continuously release bonding agents. Tillage systems with high residue addition are, in this sense, desirable (Table 2), since they allow the formation of larger and more resistant aggregates (Tables 3 and 5) that maintain the soil structure, even under external forces such as animal trampling.

To clarify the effect of grazing intensities on aggregate size distribution during grazing cycles, the aggregates were grouped in three size classes $(<0.25$, $0.25-2.00$ and $>2.00 \mathrm{~mm}$, Figure 1). For interpretation, the ungrazed treatment and largest aggregate class $(>2.00 \mathrm{~mm})$, which varied the most, were used as reference for the evolution of aggregate distribution. Thus, the highest percentages in the aggregate class $>2.00 \mathrm{~mm}$ corresponded to lowest values in the size classes $0.25-2.00 \mathrm{~mm}$ while variation was lowest in 

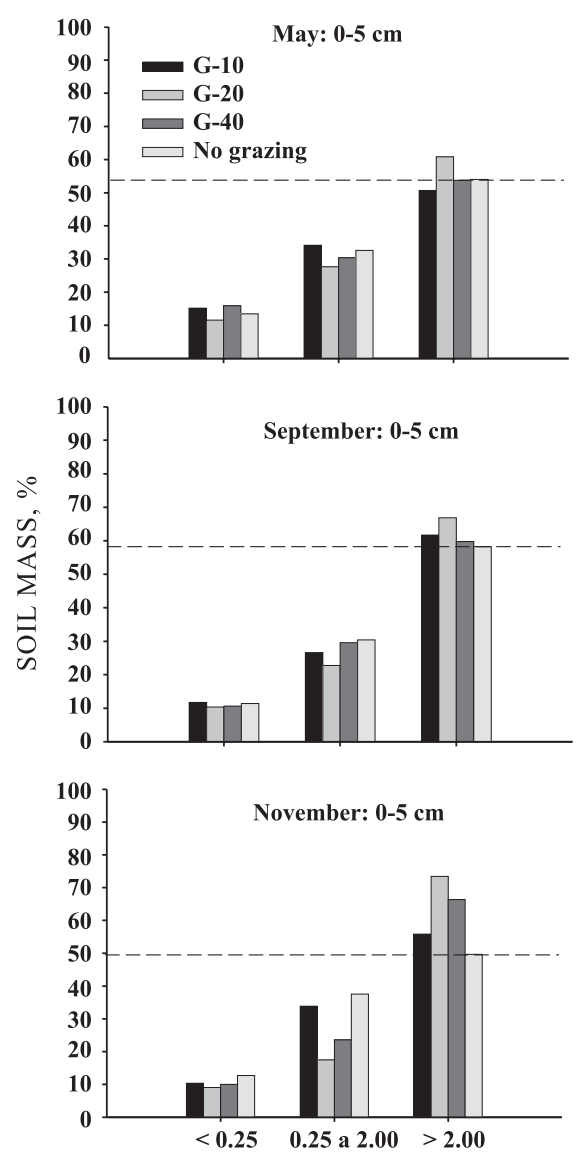
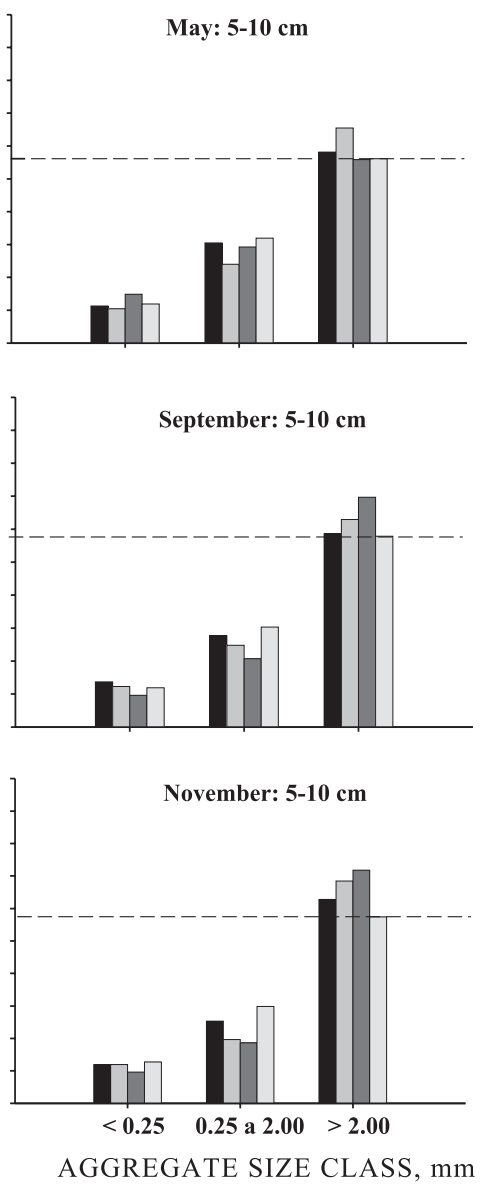
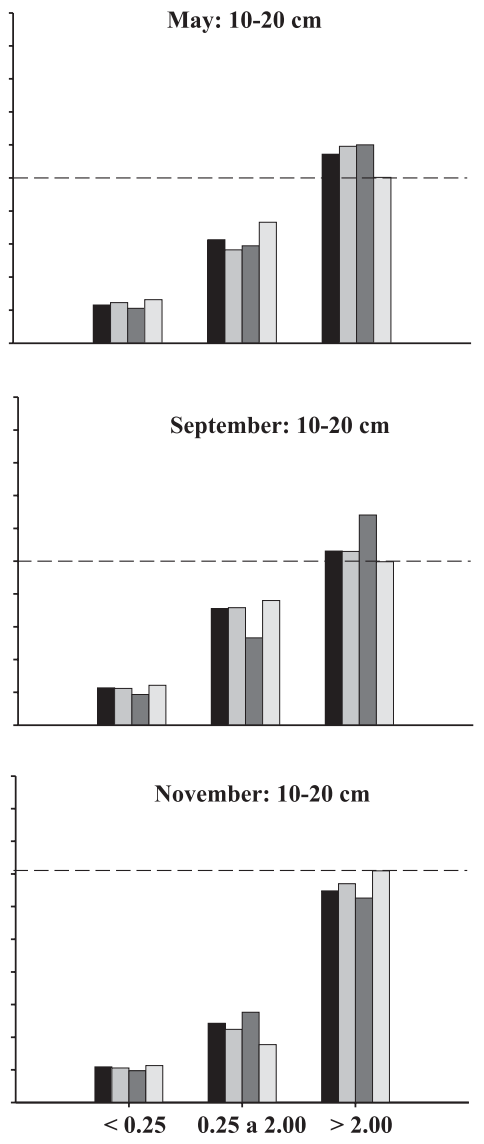

Figure 1. Water-stable aggregate distribution in different layers and samplings in a Red Latosol, grouped in three size classes for grazing intensities. ${ }^{(1)}$ G-10, G-20 and G-40 represent grazing heights of 10, 20 and $40 \mathrm{~cm}$, respectively. Dotted lines are used to differentiate values of the ungrazed area (reference).

the $<0.25$ size class, and vice-versa. Considering the results in the $0-5 \mathrm{~cm}$ layer, the most sensitive to grazing effects, the percentage values of the ungrazed treatment (55\% in May), increased (60\% in September) and thereafter decreased (50\% in November), according to the pasture growth pattern (Table 2). Meanwhile, in the grazing treatments, an increase was verified in this aggregate size class during the grazing cycle, mainly under moderate grazing (G-20 and G-40). In G-20, the percentage values of this aggregate size class in the top soil layer $(0-5 \mathrm{~cm})$ were always highest. In general, these results were the same in the $5-10 \mathrm{~cm}$ layer in the three evaluations, with an advantage, however, under G40 in the September and November evaluations and in the 10-20 cm layer in the September evaluation (Figure 1). In this layer, there was a percentage increase in the ungrazed treatment as well, in the last evaluation, when all treatments were similar.

Grazing stimulated the release of root exudates. Furthermore, wastes (urine + manure ) also influenced aggregate distribution at the moderate grazing intensities. Thus, it seems that animal presence at moderate grazing intensity improves aggregate stability, due to the high residue quantity from shoots (Table 2) as well as roots (Conte, 2007; Souza et al., 2008) under moderate grazing intensity, compared to high grazing intensity or no grazing. Yet, under moderate grazing intensity, animal trampling was beneficial, since aggregation occurred without causing soil compaction (Table 1).

A greater proportion of larger aggregates in grazed areas was also verified by the mean weighted diameter (MWD) (Table 6). Despite the numerical differences observed in this table, increases $(p<0.05)$ in MWD values with grazing period (May to September) were only verified for G-20, in the $0-5 \mathrm{~cm}$ layer, G-40, in the $5-20 \mathrm{~cm}$ layer and NG in the 10-20 cm layer. Comparing grazing intensities, differences in MWD were detected in the $0-5 \mathrm{~cm}$ layer only in the last sampling (November), at the end of the grazing cycle, as follows: G-20 $\geq \mathrm{G}-40 \geq$ and $10 \mathrm{~cm}$ grazing height $(\mathrm{G}-10) \geq \mathrm{NG}$, where $\mathrm{G}-20>\mathrm{G}-10$ and no grazing $(\mathrm{p}<0.05)$. 
In the evaluations of the aggregate size class [(Tables 3 and 5 and Figure 1 or of MWD (Table 6)], the moderate grazing intensities G-20 and G-40, were most favorable for the formation of alarger aggregates, and are therefore the managements with greatest physical protection of the organic matter. For MWD, no isolated factor would be responsible for the increase in formation of larger aggregates, but combined effects of various aggregating substances would rather be responsible for soil aggregation. However, as stated by Boeni (2007), this pattern suggests that grasses can play a beneficial role in the formation of large aggregates from the union of smaller aggregates. But in soils with predominance of 1:1 clay minerals and oxides, bonding capacity also plays an important role in aggregate stability.

In this study, residue addition varied according to grazing intensity, and was higher via roots with increasing grazing intensity (G-10 $>$ G-20 $>$ G$40>\mathrm{NG}$ ), and via shoot, with decreasing grazing intensity (NG > G-40 > G-20 > G-10) (Conte, 2007). Even in this oxide-rich soil, the effect of organic bonding agents on the formation of larger aggregates $(>2.00 \mathrm{~mm})$ seems notable, mainly because these areas are grazed for at least six months per year. According to Boeni (2007), soil consists of primary granular structures, represented by micro-aggregates $(<0.25 \mathrm{~mm})$ and part of the meso-aggregates $(0.25-$ $2.00 \mathrm{~mm}$ ), as they interact with organic agents in aggregation and stabilization, resulting in larger, and possibly carbon-richer aggregates. This author, evaluating a Latosol with similar characteristics as in this study, stated that the majority of aggregates with diameter of up to $2.00 \mathrm{~mm}$ probably result from mineral bonding agents reacting with clay and $\mathrm{Fe}$ oxide particles, which is around $274 \mathrm{mg} \mathrm{kg}^{-1}$, for the soil in this trial (Rheinheimer \& Anghinoni, 2001). According to Tisdall \& Oades (1982), the aggregate stability with diameters $>2.00 \mathrm{~mm}$ is related to root and hyphal growth; consequently, in management systems that allow continuous root growth, as in grazed areas, the proportion of aggregates in the $>2.00 \mathrm{~mm}$ class increases.

Processes which stabilize micro-aggregates are permanent so that carbon addition to the soil influences macro-aggregates, in the first place (Tisdall $\&$ Oades, 1982). Hence, grazing intensities influence the stability of large aggregates $(>2 \mathrm{~mm})$, which represent more than $50 \%$ of the soil mass (Figure 1). Salton et al. (2008) affirmed that stable aggregates are crucial for a good soil structure, providing pore space for root and fauna growth and development and water and air circulation.

The complexes formed by mineral-organic matter interaction affect water-stable aggregates size directly (Christensen, 2001). In the areas with animal presence, MWD increases with increasing soil C contents (Figure 2). This effect is more marked in the $0-5$ and $5-10 \mathrm{~cm}$ than in the $10-20 \mathrm{~cm}$ layer. This effect confirms results of Haynes \& Beare (1997) who related aggregate stability to organic residue addition by crops and the presence of soil organic matter and higher microbial activity, which are important cementing agents of soil aggregates and an energy source for microorganism (Paladini \& Mielniczuk, 1991).

Table 6. Mean weighted diameter of water-stable aggregates in different layers of a Red Latosol in an integrated no-tillage crop-livestock system under different grazing intensities

\begin{tabular}{|c|c|c|c|c|c|}
\hline \multirow[b]{2}{*}{ Month/2007 } & \multicolumn{5}{|c|}{ Grazing intensity $^{(1)}$} \\
\hline & $G-10^{(1)}$ & G-20 & $G-40$ & NG & Average \\
\hline & \multicolumn{5}{|c|}{0 to $5 \mathrm{~cm}$ layer } \\
\hline May & $3.3 \mathrm{aA}$ & $4.0 \mathrm{bA}$ & $3.5 \mathrm{aA}$ & $3.3 \mathrm{aA}$ & 3.5 \\
\hline September & $3.9 \mathrm{aA}$ & $4.3 \mathrm{abA}$ & $3.9 \mathrm{aA}$ & $3.6 \mathrm{aA}$ & 3.9 \\
\hline November & $3.4 \mathrm{aB}$ & $4.8 \mathrm{aA}$ & $4.2 \mathrm{aAB}$ & $3.1 \mathrm{aB}$ & 3.9 \\
\hline \multirow[t]{2}{*}{ Average } & 3.5 & 4.4 & 3.8 & 3.3 & \\
\hline & \multicolumn{5}{|c|}{5 to $10 \mathrm{~cm}$ layer } \\
\hline Maio & $3.5 \mathrm{aA}$ & $4.1 \mathrm{aA}$ & $3.5 \mathrm{bA}$ & $3.3 \mathrm{aA}$ & 3.6 \\
\hline Setembro & $3.7 \mathrm{aA}$ & $3.9 \mathrm{aA}$ & $4.5 \mathrm{aA}$ & $3.5 \mathrm{aA}$ & 3.9 \\
\hline Novembro & $3.9 \mathrm{aA}$ & $4.4 \mathrm{aA}$ & $4.5 \mathrm{aA}$ & $3.7 \mathrm{aA}$ & 4.1 \\
\hline \multirow[t]{2}{*}{ Média } & 3.7 & 4.1 & 4.2 & 3.5 & \\
\hline & \multicolumn{5}{|c|}{10 to $20 \mathrm{~cm}$ layer } \\
\hline May & $3.5 \mathrm{abA}$ & $3.6 \mathrm{abA}$ & 3.7 & $3.0 \mathrm{bA}$ & 3.4 \\
\hline September & $3.1 \mathrm{bA}$ & $3.2 \mathrm{bA}$ & $3.9 \mathrm{aA}$ & $3.0 \mathrm{bA}$ & 3.3 \\
\hline November & $4.1 \mathrm{aA}$ & $4.0 \mathrm{aA}$ & $3.7 \mathrm{aA}$ & $4.5 \mathrm{aA}$ & 4.1 \\
\hline Average & 3.5 & 3.6 & 3.8 & 3,5 & \\
\hline
\end{tabular}

(1) G-10, G-20, G-40 and NG represent grazing heights of 10, 20, $40 \mathrm{~cm}$ and ungrazed treatment, respectively. Small letters followed by the same small letters, in the columns, compare the effect of different periods in each treatment in the same layer. Capital letters, in the rows, compare the effect of treatments for each period. Same letters do not differ from each other by the Tukey test at $5 \%$. 


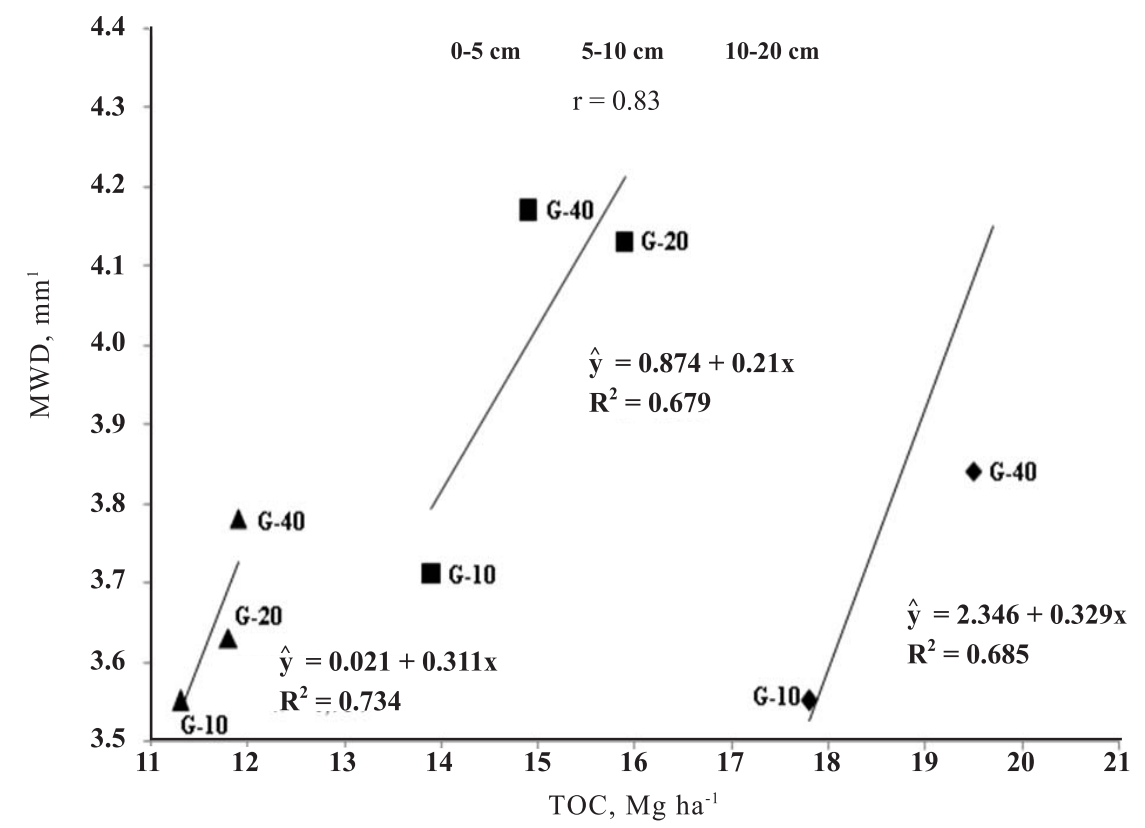

Figure 2. Relation between total organic carbon stocks (TOC) and mean weighted diameter (MWD) of waterstable aggregates in the layers 0-5, 5-10 and 10-20 cm in a Red Latosol under integrated no-tillage croplivestock system under different grazing intensities. G-10, G-20, G-40 and ng represent 10, 20, 40 cm grazing heights and ungrazed treatment, respectively.

\section{CONCLUSIONS}

1. Soil aggregation in the integrated crop-livestock systems under grazing subjected to no-tillage was higher than in ungrazed areas, mainly in the surface layer $(0-5 \mathrm{~cm})$ and under moderate grazing $(20 \mathrm{~cm}$ pasture height).

2. Increase in aggregation formation during the pasture cycle occurs both in ungrazed areas, according to the plant development, mainly of root growth, as well as in grazed areas, where it is more evident under light and moderate grazing intensities.

\section{LITERATURE CITED}

ALLISON, F.E. Soil organic matter and its role in crop production. Amsterdam, Elsevier, 1973. p.215-345.

BAVER, L.D.; GARDNER, W.H. \& GARDNER, W.R. Física de suelos. Barcelona, Union Tipográfica Editorial HispanoAmericana, 1973. 529p.

BAYER, C.; MIELNICZUK, J.; AMADO, T.J.C.; MARTIN NETO, L. \& FERNANDES, S.V. Organic matter storage in a sandy clay loam Acrisol affected by tillage and cropping systems in southern Brazil. Soil Tillage Res., 54:101-109, 2000 .

BEUTLER, A.N.; SILVA, M.L.N.; CURI, N.; FERREIRA, M.M.; PEREIRA FILHO, I.A. \& CRUZ, J.C. Agregação de Latossolo Vermelho distrófico típico relacionado com o manejo na região dos cerrados no estado de Minas Gerais. R. Bras. Ci. Solo, 25:129-136, 2001.
BIRCHAM, J.S. Herbage growth and utilization under continuous stocking management. Edinburgh, University of Edinburgh, 1981. (Tese de Doutorado)

BOENI, M. Proteção física da matéria orgânica em Latossolos sob sistemas com pastagens na região do Cerrado brasileiro. Porto Alegre, Universidade Federal do Rio Grande do Sul, 2007. 136p. (Tese de Doutorado)

CAMBARDELLA, C.A. \& ELLIOT, E.T. Particulate soil organicmatter changes across a grassland cultivation sequence. Soil Sci. Soc. Am. J., 56:777-783, 1992.

CARPENEDO, V. \& MIELNICZUK, J. Estado de agregação e qualidade de agregados de Latossolos Roxos, submetidos a diferentes sistemas de manejo. R. Bras. Ci. Solo, 14:99105,1990

CHRISTENSEN, B.T. Physical fractionation of soil and structural and functional complexity in organic matter turnover. Europ. J. Soil Sci., 52:345-353, 2001.

COMISSÃO DE QUÍMICA E FERTILIDADE DO SOLO CQFS-RS/SC. Manual de adubação e de calagem para os Estados do Rio Grande do Sul e Santa Catarina. Porto Alegre, Sociedade Brasileira de Ciência do Solo/Núcleo Regional Sul, 2004.

CONCEIÇÃO, P.C. Proteção física da matéria orgânica do solo em solos do Sul do Brasil. Porto Alegre, Universidade Federal do Rio Grande do Sul, 2006. 145p. (Tese de Doutorado)

CONTE, O. Atributos físicos de solo e demanda de tração em semeadura direta de soja, com diferentes pressões de pastejo em sistema de integração lavoura-pecuária. Porto Alegre, Universidade Federal do Rio Grande do Sul, 2007. 91p. (Tese de Mestrado) 
DEXTER, A.R. Advances in characterization of soil structure. Soil Tillage Res., 11:199-238, 1988.

EMPRESA BRASILEIRA DE PESQUISA AGROPECUÁRIA EMBRAPA. Centro Nacional de Pesquisa de Solos. Sistema brasileiro de classificação de solos. Rio de Janeiro, 2006. 306p.

HAYNES, R.J. \& BEARE, M.H. Influence of six crop species on aggregate stability and some labile organic matter fractions. Soil Biol. Biochem., 29:1647-1653, 1997.

KARLEN, D.L. \& STOTT, D.E. A framework for evaluating physical and chemical indicators of soil quality. In: DORAN, J.W.; COLEMAN, D.C.; BZEDICEK, D.F. \& STEWART, B.A., eds. Defining soil quality for a sustainable environment. Madison, Soil Science Society of America, 1994. p.53-72. (Special Publication, 35)

KEMPER, W.D. \& CHEPIL, W.S. Size distribution of aggregation. In.: BLACK, C.A., eds. Methods of soil analysis. Madison, American Society of Agronomy, 1965. p.499-510.

OADES, J.M. Soil organic matter and structural stability: mechanisms and implications for management. Plant Soil, 76:319-337, 1984.

PALADINI, F.L.S. \& MIELNICZUK, J. Distribuição de tamanho de agregados de um Podzólico Vermelho-Escuro afetado por sistemas de cultura. R. Bras. Ci. Solo, 15:135-140, 1991.

REINERT, D.J. Recuperação da agregação pelo uso de leguminosas e gramíneas em solo Podzólico VermelhoAmarelo. Santa Maria, Universidade Federal de Santa Maria, 1993. 62p.
REUNIÃO DE PESQUISA DE SOJA DA REGIÃO SUL. Indicações técnicas para cultura de soja no Rio Grande do Sul e Santa Catarina. Passo Fundo, Embrapa Trigo, 2004. $172 \mathrm{p}$.

RHEINHEIMER, D.S. \& ANGHINONI, I. Distribuição do fósforo inorgânico em sistemas de manejo de solo. Pesq. Agropec. Bras., 36:151-160, 2001.

SALTON, J.C.; MIELNICZUK, J.; BAYER, C.; BOENI, M.; CONCEIÇÃO, P.C.; FABRÍCIO, A.C.; MACEDO, M.C.M. \& BROCH, D.L. Agregação e estabilidade de agregados do solo em sistemas agropecuários em Mato Grosso do Sul. R. Bras. Ci. Solo, 32:11-21, 2008.

SILVA, I.F. \& MIELNICZUK, J. Avaliação do estado de agregação do solo afetado pelo uso agrícola. R. Bras. Ci. Solo, 21:313-319, 1997.

SILVA, V.R.; REINERT, D.J. \& REICHERT, J.M. Densidade do solo, atributos químicos e sistema radicular do milho afetados pelo pastejo e manejo do solo. R. Bras. Ci. Solo, 24:191-199, 2000.

SOUZA, E.D.; COSTA, S.E.V.G.A.; LIMA, C.V.S.; ANGHINONI, I.; MEURER, E.J. \& CARVALHO, P.C.F. Carbono orgânico e fósforo microbiano em sistemas de integração agricultura-pecuária submetidos a diferentes intensidades de pastejo em plantio direto. R. Bras. Ci. Solo, 32:1273$1282,2008$.

TEDESCO, M.J.; GIANELLO, C. \& BISSANI, C.A. Análises de solo, plantas e outros materiais. 2.ed. Porto Alegre, Universidade Federal do Rio Grande do Sul, 1995. 174p.

TISDALL, J.M. \& OADES, J.M. Organic matter and waterstable aggregates in soil. J. Soil Sci., 33:141-163, 1982. 